\title{
THE STUDY OF THE IMPACT OF E-COMMERCE ACTIVITIES ON FIRM VALUE AND THE RELATIONSHIP BETWEEN E-MARKETING AND FIRM VALUE
}

\section{DOI: 10.17261/Pressacademia.2017...}

JEFA- V.-ISS.2-2017(1)-p.112-120

\author{
Mustafa Yurttadur ${ }^{1}$, Cansu Turker ${ }^{2}$ \\ ${ }^{1}$ Istanbul Gelisim University, Faculty of Economics, Administrative and Social Sciences, Istanbul, Turkey. myurttadur@gelisim.edu.tr \\ ${ }^{2}$ Istanbul Gelisim University, Faculty of Economics, Administrative and Social Sciences, Istanbul, Turkey. cturker@gelisim.edu.tr
}

To cite this document

Yurttadur, M. and Turker, C., (2017). The study of the impact of e-commerce activities on firm value and the relationship between e-marketing and firm value. Journal of Economics, Finance and Accounting (JEFA), V.4, Iss.2, p.112-120

Permemant link to this document: http://doi.org/10.17261/Pressacademia.2017.

Copyright: Published by PressAcademia and limited licenced re-use rights only.

\begin{abstract}
Purpose- This study aims to explain the importance of the internet activities for companies' marketing strategies to add some value to the company. - E-marketing activites, which add value to a firm, should be taken into consideration during decision making process. Therefore, calculating the return on e-marketing activities investments is useful for both finance and marketing specialists.

Methodology- - In this study, the effects of e-commerce activities on firm value regarding tangible and intangible assets are examined. Financial statements are analyzed for determining tangible assets. E-marketing activities are taken into consideration as intangible assets and whether these activities affect firm value or not are analyzed. Accordingly, in this study, the firm value before and after launching emarketing activities as well as the change among the factors which add value to a firm are analyzed in detail.

Findings- - The relationship between firm value and the predetermined data of e-marketing activities is analyzed. The study first dwells on the factors which affect firm value and shareholder value, and then on whether there is any difference between the factors before and after launching e-marketing activities. Findings show that businesses have increased their firm value after they started e-commerce.

Conclusion- As a conclusion, after the introduction of e-commerce operations, it became clear that firm value of the companies increased but starting e-commerce activities in early years doesn't bring the competitive advantage to the early adapters of e-commerce.
\end{abstract}

Keywords: Firm value, e-marketing, e-commerce, social media, financial performance.

JEL Codes: G14, G32, M21, M31

\section{INTRODUCTION}

With the development of technology and internet, almost all the information can be obtained, information can be provided and communication with others are within the bounds of possibility. These possibilities and innovations bring new opportunities to the businesses. When the Internet is considered as a part of everyone's life, the retail industry has begun to follow these developments closely. By adopting these innovations and developing them for their own sector, firms are looking for solutions for making people's life easier. In the light of these developments, businesses are working to improve and differentiate the values that they present to the consumers. Usage of the internet in the retail sector; effective communication with business partners, introduction of company products, inventory control. Besides of these areas, internet is also used for online commerce also known as e-commerce by the firms. E-commerce is a powerful alternative for traditional commerce. E-commerce brings many cost cuttings and opportunities to the firms, but it also brings some expenses and investment requirements to the firms. Development of the technology in this direction differentiate promotion activities from traditional marketing mix. The differentiations between traditional promotion and the new one lead us to e-marketing activities which are very important factors in e-commerce. 
The change in technology and consumer's purchasing habits encourage businesses to be more conscious of the investments they make on online channels. Companies must measure the return of its investments on online platforms and make decisions accordingly. These measurement methods are designed to maximize the interests of both the consumer and the firm. In this study, whether the retail enterprises in Turkey, which started performing e-commerce operations, made any difference in their firm value is analyzed. Moreover, the relation of the determined e-marketing data set with the firm value is examined. The starting point of this research is to associate companies' innovative marketing investments with company value within changing technological environment. Because of these relationships are getting more important for both marketing and financial specialists, further research has been conducted. The research of Özmen and Villi reveals the importance of social media and financial performance (Özmen \& Villi, 2014).

This study aims to bring a perspective of the importance of measure return on e-marketing investments. This study can be important for two reasons. The first one is online platforms and online marketing applications are a new subject in the literature and the second is that this study can give ideas about e-marketing investments to businesses within the constantly changing structure of technology. Starting e-commerce activities enables firms to gain an operational and strategic advantage. It is important to have an innovative and predictive management approach, considering its contribution to market value of the firms and gaining competitive advantage in growing and developing online market. Revealing this relationship is also important for academic field (Subramani \& Walden, 2001). Findings about the relationship between e-commerce activities and firm value in the research which was conducted by Submarini and Walden, contributes to the solution of our research problem.

This paper begin with explaining e-marketing activities, e-commerce and its development, then continues with analyzing nine retail companies firm value and its relationship with the e-commerce and e-marketing activities.

\section{LITERATURE REVIEW}

\subsection{E-Commerce}

There are various definitions in the literature for e-commerce which can be expressed as an alternative to traditional trade. The reason why it is not possible to depend on a single definition can be explained by technological developments which are constantly changing. In the literature; e-commerce is defined as an exchange process using the digital technology in the internet environment (Schniederjans et al., 2014). According to the definition of the Ministry of Economy, electronic trading is a three-step process of transactions in the internet environment, which can be accessed by technological means, including advertising and market research, ordering and payment and delivery (ekonomi.gov.tr, retrieved from: 14.03.2017). Another definition of e-commerce is defined by World Trade Organization (WTO) is production, marketing mix, sales and delivery of products and services electronically (wto.org, retrieved from: 14.03.2017). Taking all these definitions into consideration, electronic commerce can be defined as the possibility of purchasing products and services through web sites presented by internet-based business models.

\subsection{Development of E-Commerce}

Development of the web enables exchanging information easier and spreading the information faster. While developments are ongoing, such as the exchange of information and banking transactions, businesses realize that selling products and services over the web can be cheaper and faster. The widespread use of the e-commerce both on behalf of consumers and on behalf of businesses' purchases and sales is rapidly growing with technological developments (Kalakota \& Whinston, 1997).

The concept of electronic commerce was first debated in Turkey in 1997. In the Supreme Council of Science and Technology, it has been decided to start working on the development and dissemination of electronic commerce in Turkey (ekonomi.gov.tr, retrieved from: 14.03.2017). Electronic commerce is a form of trade made by telephone, fax, television, electronic payment and money transfer systems, electronic data interchange (EDI) and Internet tools (Sarısakal, 2002). Today, as technology develops and the internet has an important place in people's lives, e-commerce applications have been moved to internet platforms. Retailers who have started e-commerce activities are able to win new opportunities, new sales and new customers in global markets (Enginkaya, 2006). E-commerce present many advantages to consumers as much as the firms do. Consumers are offered a limited number and variety of products in stores where the diversity and stocks are wider in the internet environment. Consumers are offered the opportunity of making purchases wherever they want without having to physically go to the store (Galant et al., 2002).

\subsection{The Role of E-Marketing in E-Commerce}

The term of e-marketing is emerged with the changing concepts of marketing activities that develop in the online environment. With the development of e-commerce, distribution channels, communication activities, prices and methods of reaching products and services have been moved to a different dimension. In the light of these developments, marketing 
activities gain importance in online platforms. E-marketing is the concept that brings consumers and businesses together through technology, especially internet. E-marketing includes interactive technologies, customer relationship management, sales, research, analysis and planning (Brodie et al, 2007). The great advantage of e-marketing in terms of businesses is bringing the opportunity of making products and services easily accessible for the target customers that cannot reach these products and services due to some temporary reasons or location. E-marketing has led to the passing of favorable practices both from the point of view of the business and of the consumers by increasing access rates and reducing costs (Sheth \& Sharma, 2005).

E-marketing activities can vary according to the methods used, communication factors, applications, brands, products and services. The common mistake is the reduction of e-marketing by two variables as building a website and internet advertising. It should be kept in mind that many factors, such as marketing activities, integrated marketing communication, customer communication management, carrying brand image on online platforms are also included in the scope of emarketing (Krishnamurthy, 2006).

\subsection{The Importance of E-Commerce Activities in Terms of Firm Value}

Companies run their operations in order to reach general goals of all enterprises have such as increasing firm value and making profit as well as to reach their own specific purposes. Each of these goals has different significance levels at different times. Firm value is one of the top priorities for all businesses. Determination of the value of the firm is important in terms of the financial institutions, investors and firm partners related to the company (Birgili \& Düzer, 2010). Factors that generate firm value are defined as any variable that affects business value. These elements are also tools that show the growth potential of the business (Külter \& Demirgüneş, 2006). A study was conducted on the effects of innovations on firms' financial performance and firm value in 2004 (Pauwels et al., 2004). In the literature, it is seen that the opinions are dominant that the innovative companies are more likely to increase their firm values. Starting e-commerce operations provide strategic and operational advantages for the companies. For this reason, it can be said that positive approach of potential investors to these activities, indicating future value of firms (Subramani \& Walden, 2001). Potential of increasing firm value brings new investment areas to the firms. These investments include online marketing expenditures that ecommerce activities cause. Where e-commerce and e-marketing investments are made, businesses are liable to their partners, what is the business' e-commerce investment to bring to the partners. For this reason, it is important to understand what these activities mean for the company, both in terms of sector and academic aspect. Variables in the measurement of these activities may vary according to the sector, the firm and the valuation method. In Zhu and Kraemer's study, e-commerce activities that affect firm value are considered as infrastructures and e-commerce capacity (Zhu \& Kreamer, 2002). The measurement of the effectiveness of innovations applied by companies is important to be interpreted according to the way they contribute to firm value.

\section{DATA AND METHODOLOGY}

Main purpose of this study is to reveal the relationship between e-marketing activities and firm values of retail enterprises which operates e-commerce in Turkey. The return on investments of e-commerce and e-marketing activities and their effects on firm value are examined in detail. This research aims to reveal a perspective in financial dimension of firms. In the scope of the research, the relationship between the online performance of the companies and the financial performance of the firms can be defined and changes of the firm value before and after the e-commerce investments are calculated.

In the research, financial tables of 9 retail companies which were published on the Public Disclosure Platform (www.kap.gov.tr) and firms' official websites are provided. To compare the difference of firm value, first financial statements are regarded in 2016 and before they have started e-commerce operations. Company equity items, debts and cash assets items were taken into account from the financial statements.

The formula used for this purpose is as follows:

FIRM VALUE = DEBTS + OWNER'S EQUITY - CASH

With this formula, value of nine firms are calculated to determine the difference of firm value before and after e-commerce activities start. To examine the effects of e-marketing activities on firm value, predetermined indicators that make up the research data set, from the related social networks Facebook, Twitter and Instagram, the rankings of the sites in Turkey, the average daily visitor and daily page views are provided from www.alexa.com. Alexa.com makes websites' traffic information and rankings accessible. Alexa's traffic estimates are based on data from its global traffic panel. For the data set prepared to measure e-marketing activities, Hoffman and Fodor's "Relevant Metrics For Social Media Applications Organized By Key Social Media Objectives" scale was utilized. The scale is divided into brand awareness, brand loyalty and word of mouth dimensions and includes measurement formats used in online applications.

Number of social media followers, rankings of firm's website, average daily visitors and daily page views are taken as the emarketing activities indicators. These indicators lead this study to the findings and interpretations of the firms. 


\section{FINDINGS AND DISCUSSIONS}

In this study, a comparison was made between the company values of the previous year and of the year in which companies started e-marketing and the company values of the year 2016 in order to determine the degree of change in the value.

Table 1: Carrefoursa, Predetermined Marketing Data Set and Firm Value Change

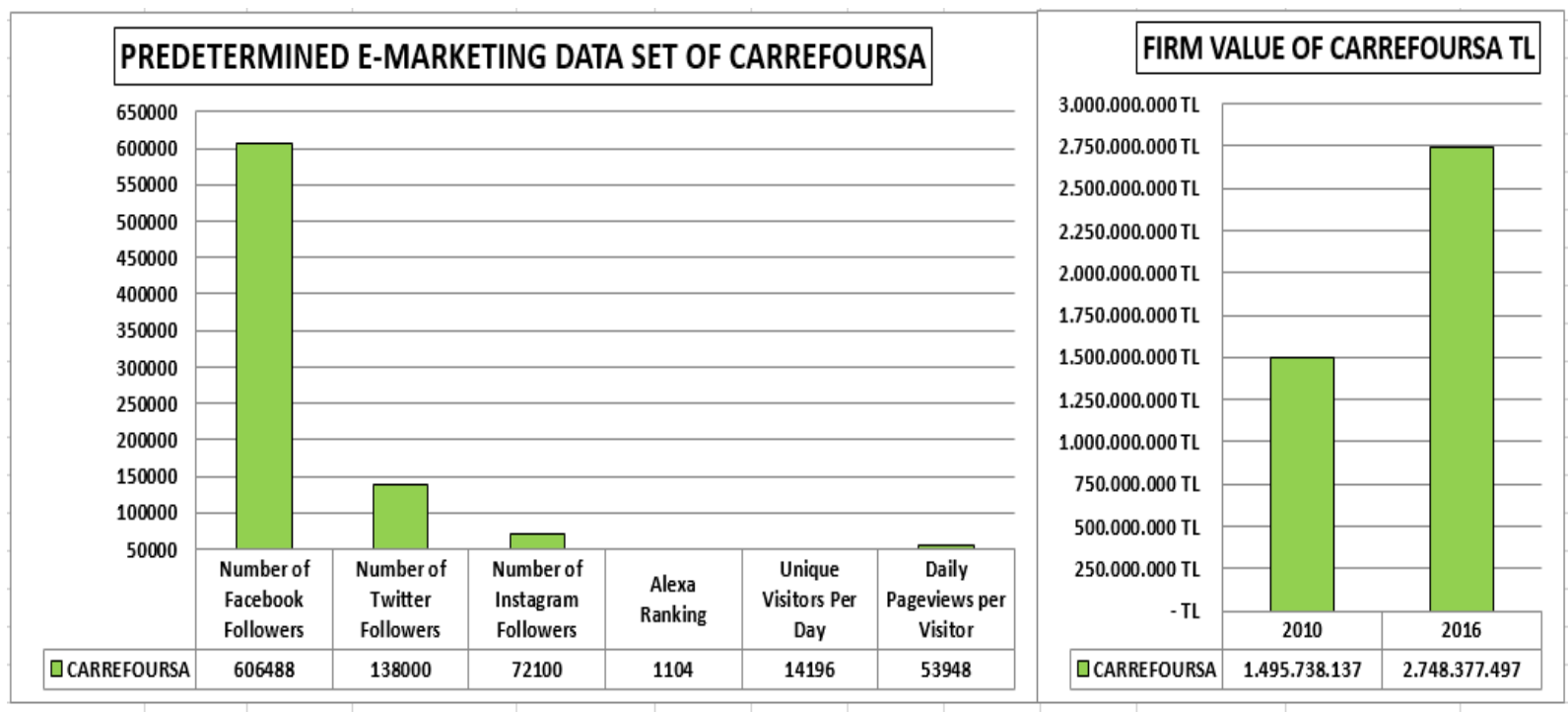

As shown in Table 1, the biggest number of followers of Carrefoursa among social media platforms are on Facebook. It was understood that the firm value increased by about $84 \%$ after firm has started e-commerce activities. Thus, e-marketing has reached the point where it affects company value at a very high level.

Table 2: Migros, Predetermined Marketing Data Set and Firm Value Change

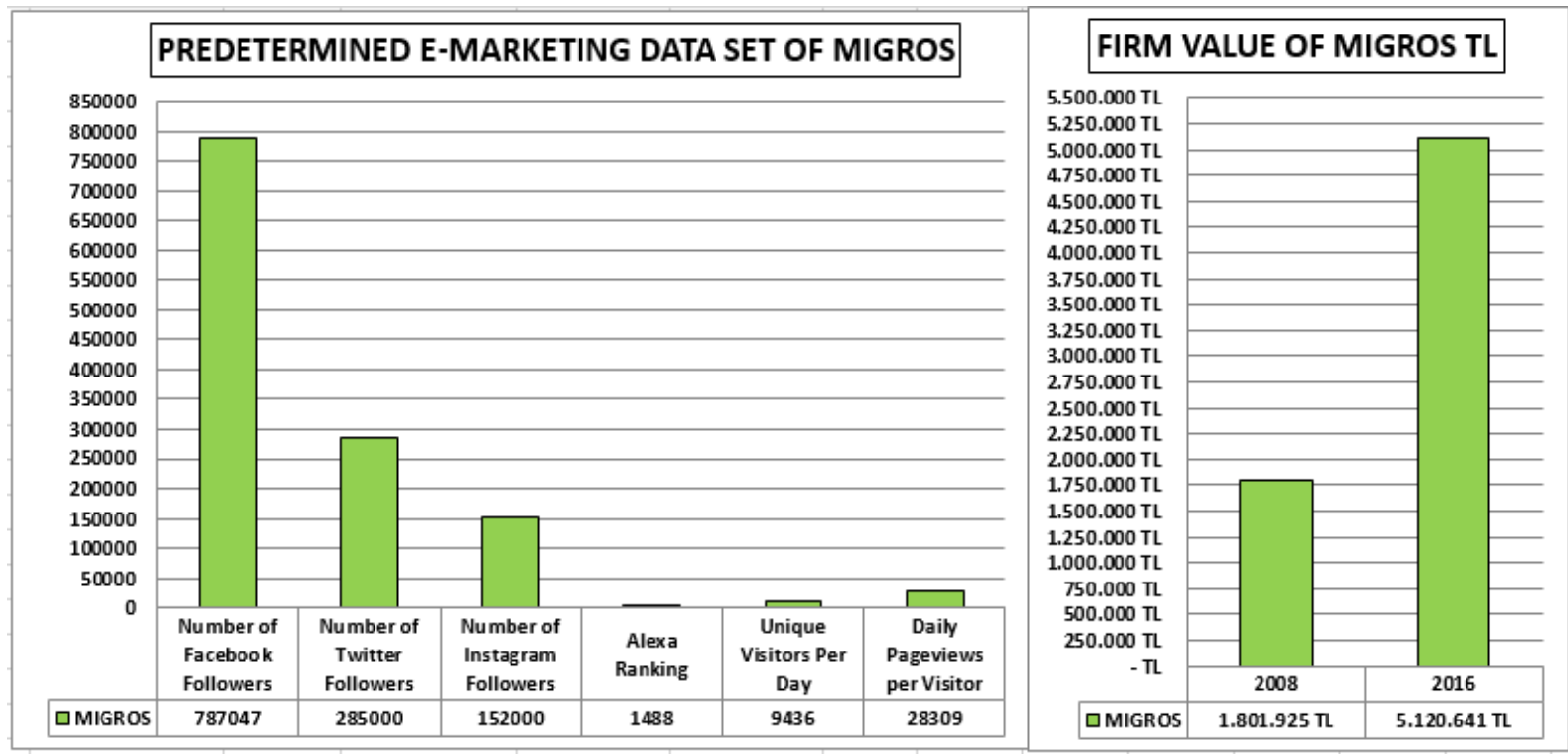

As shown in Table 2 , for Migros, most of the followers are on Facebook. The value of the firm after starting e-commerce operations (according to financial statements of the first 9 months of 2016) increased approximately by \%284. Therefore, emarketing has reached the point where it affects the company's value positively. When a comparison is made between Migros and Carrefoursa, considering that they are running businesses in the same sector, it is understood that Migros' emarketing application is reflected more efficiently as a result of the proportionally larger growth of the firm value compared to Carrefoursa. 
Table 3: Bimeks, Predetermined Marketing Data Set and Firm Value Change

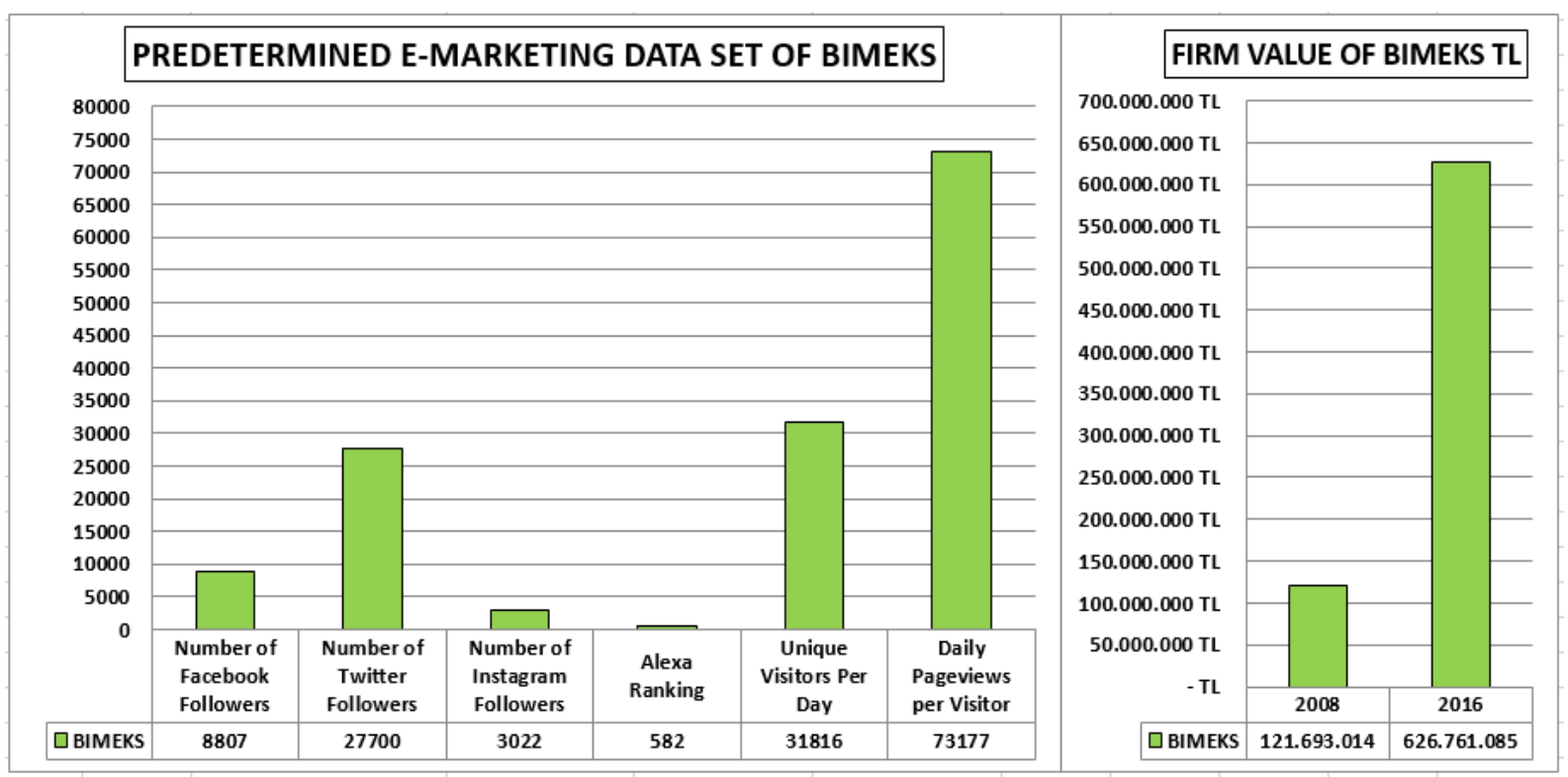

As shown in Table 3, for Bimeks, it is seen that the most of the followers are on Twitter. It is calculated that the firm value after e-marketing (financial data of the first 9 months of 2016) increased by $510 \%$. This figure shows that the company value is increased about 5 times higher. Therefore, e-marketing has reached the point where it affects the company's value positively.

Table 4: Teknosa, Predetermined Marketing Data Set and Firm Value Change

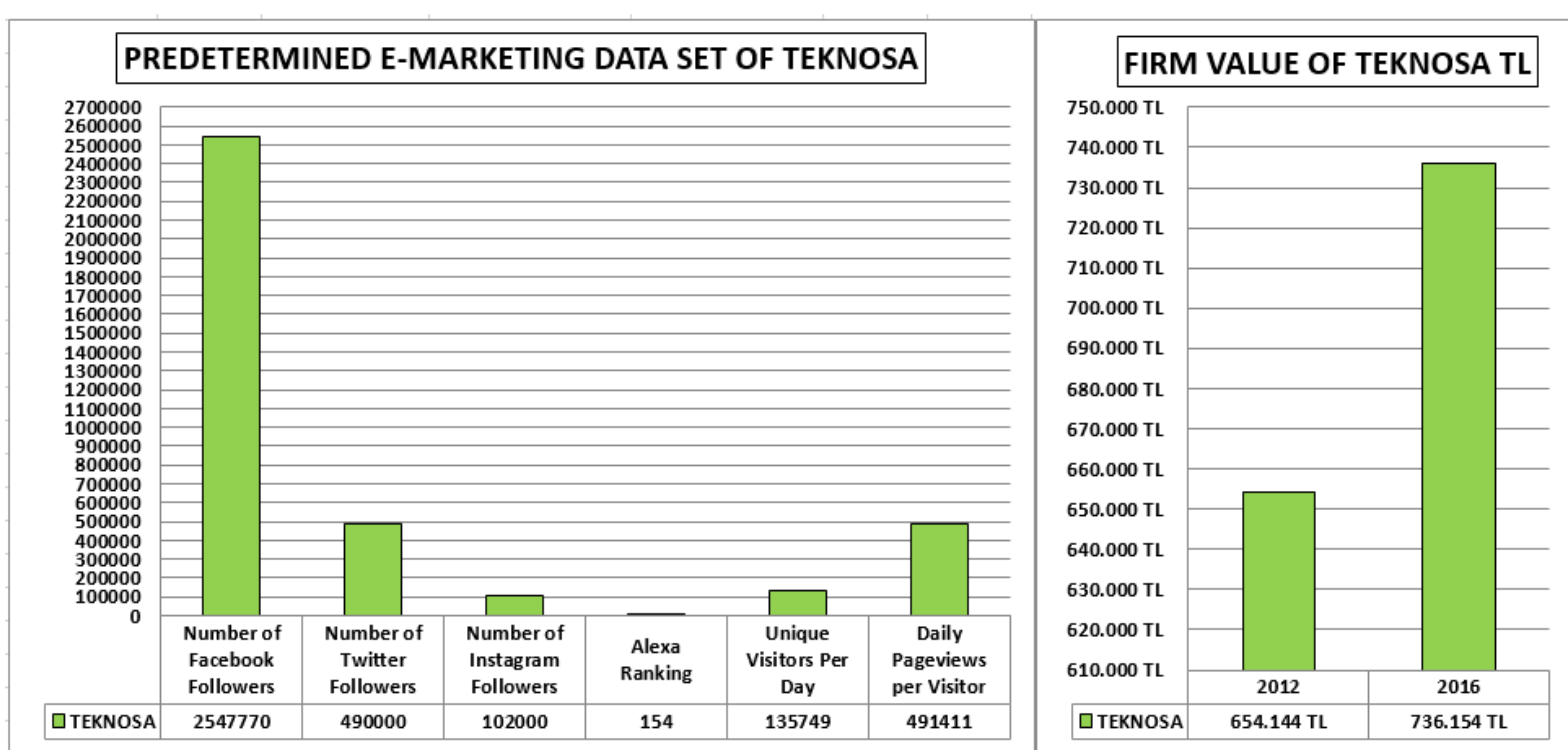

As seen in Table 4, the most of the internet followers of Teknosa are Facebook users. It has been calculated that the value of the As shown in Table 1positively. When a comparison is made between Teknosa and Bimeks, considering they are operating in the same sector, it has been understood that Bimeks's corporate value has grown more proportionally than Teknosa, resulting in e-marketing implementation being reflected more efficiently in the sector. 
Table 5: Desa, Predetermined Marketing Data Set and Firm Value Change

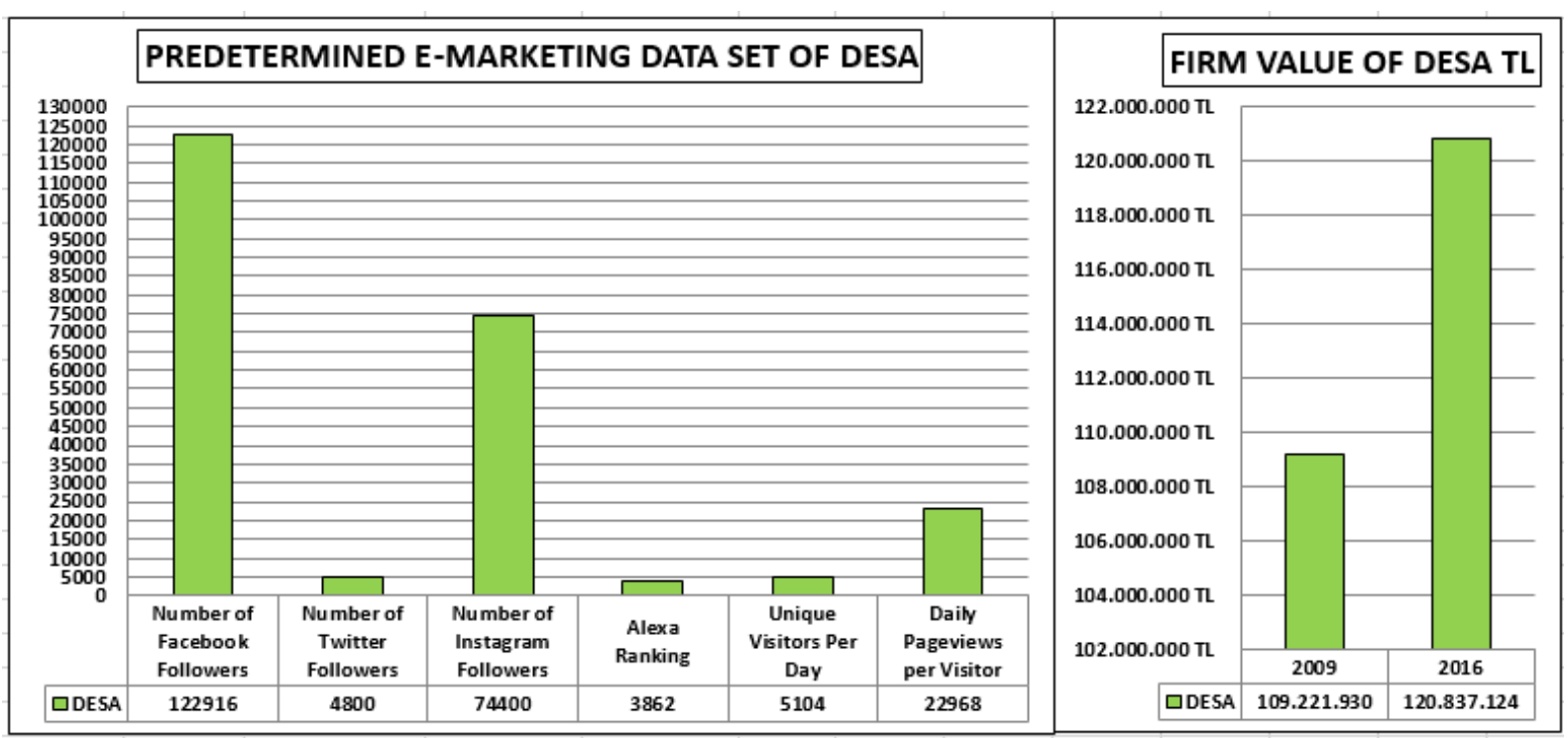

As shown in Table 5, Desa has the largest number of internet followers on Facebook, and that the company value after ecommerce activities has begun to increase by about 11\% (compared to the first 6 months of 2016). Therefore, e-marketing has reached the point where it affects the company's value positively.

Table 6: Derimod, Predetermined Marketing Data Set and Firm Value Change

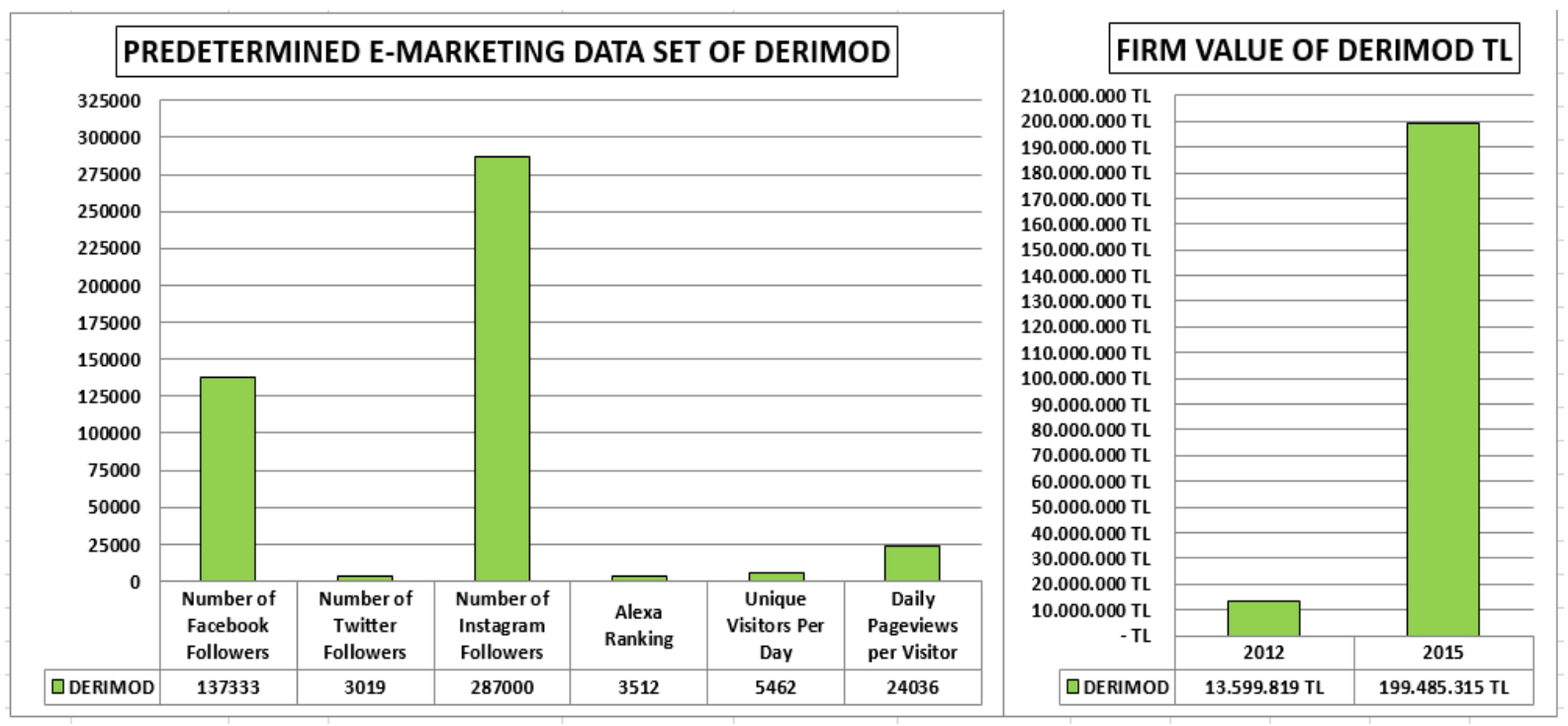

As seen in Table 6, Derimod has the largest number of followers on Instagram, and the firm value after the start of ecommerce operations is increased by $1400 \%$, by about 14 times (according to the financial statements of 2015). Therefore, e-marketing affects company's value positively. When a comparison between Derimod and Desa is made, considering they are running businesses at the same sector, it is understood that Derimod's firm value grew more proportionally compared to Desa, reflecting the effectiveness of e-marketing in the sector more efficiently. 
Table 7: Boyner, Predetermined Marketing Data Set and Firm Value Change

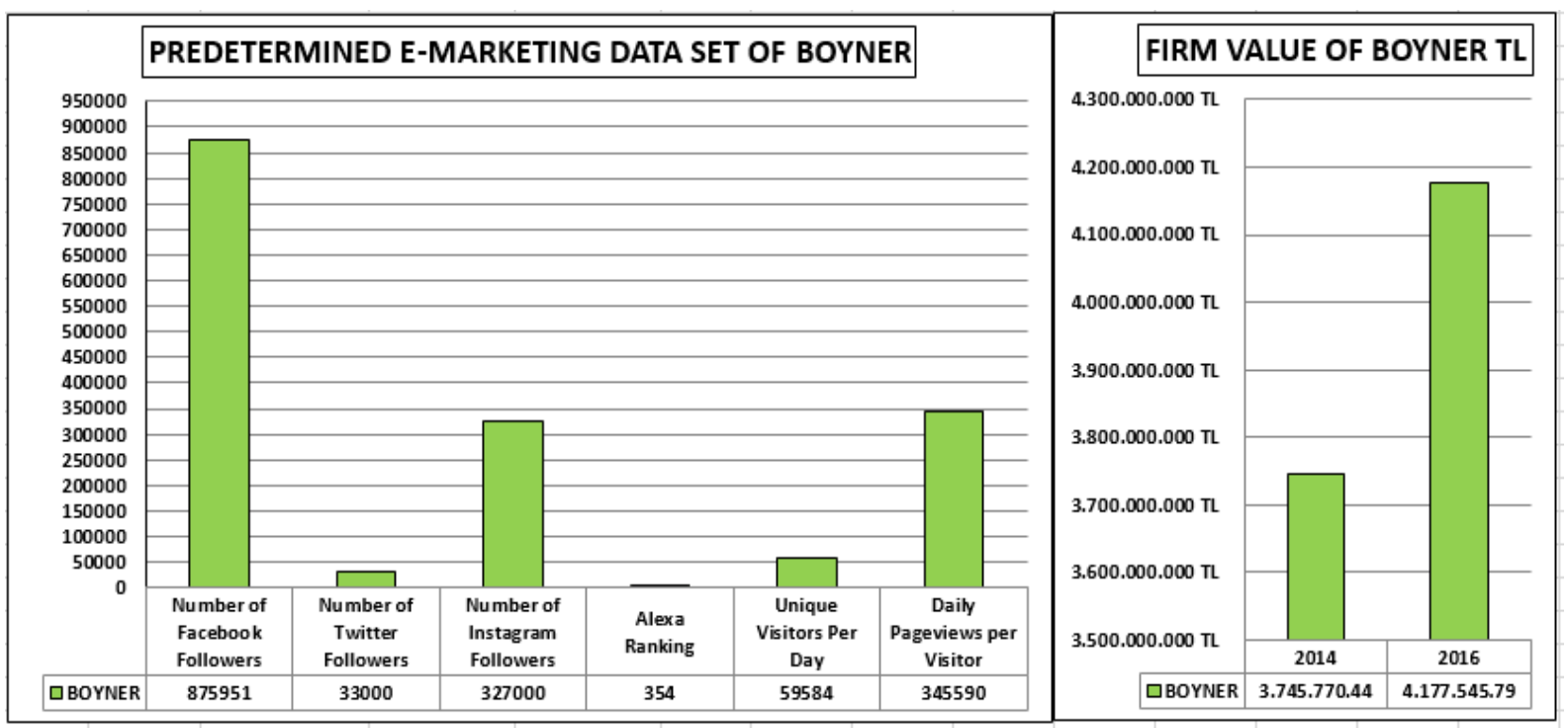

As seen in Table 7, Boyner has the largest number of internet followers on Facebook and about 11\% (before the first 6 months of 2016) of pre-e-marketing and post-company values. Therefore, e-marketing has reached the point where it affects the company's value positively.

Table 8: Dagi, Predetermined Marketing Data Set and Firm Value Change

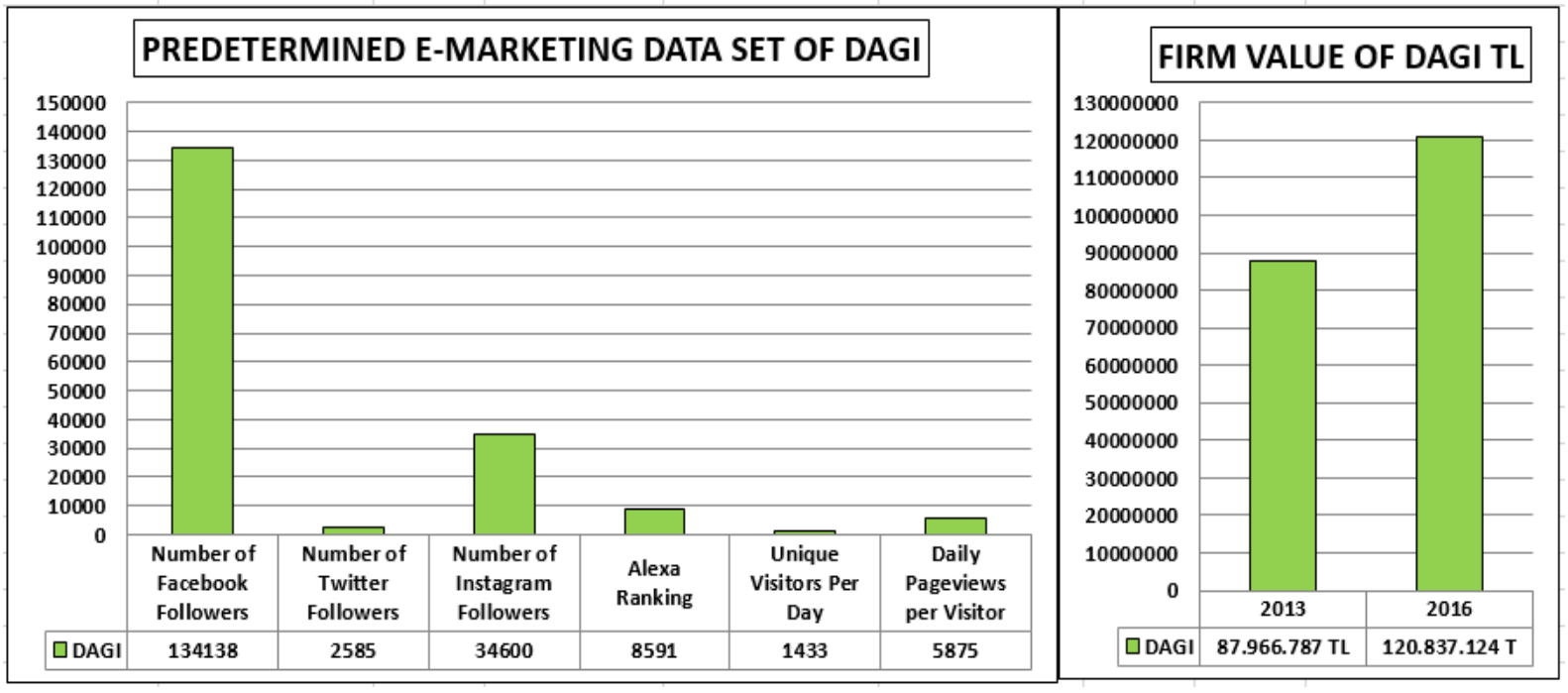

As shown in Table 8, Dagi has the largest number of internet followers on Facebook and firm value has increased by $38 \%$ after it started e-commerce activities. Therefore, e-marketing has reached the point where it affects the company's value positively. 
Table 9: Pasabahce, Predetermined Marketing Data Set and Firm Value Change

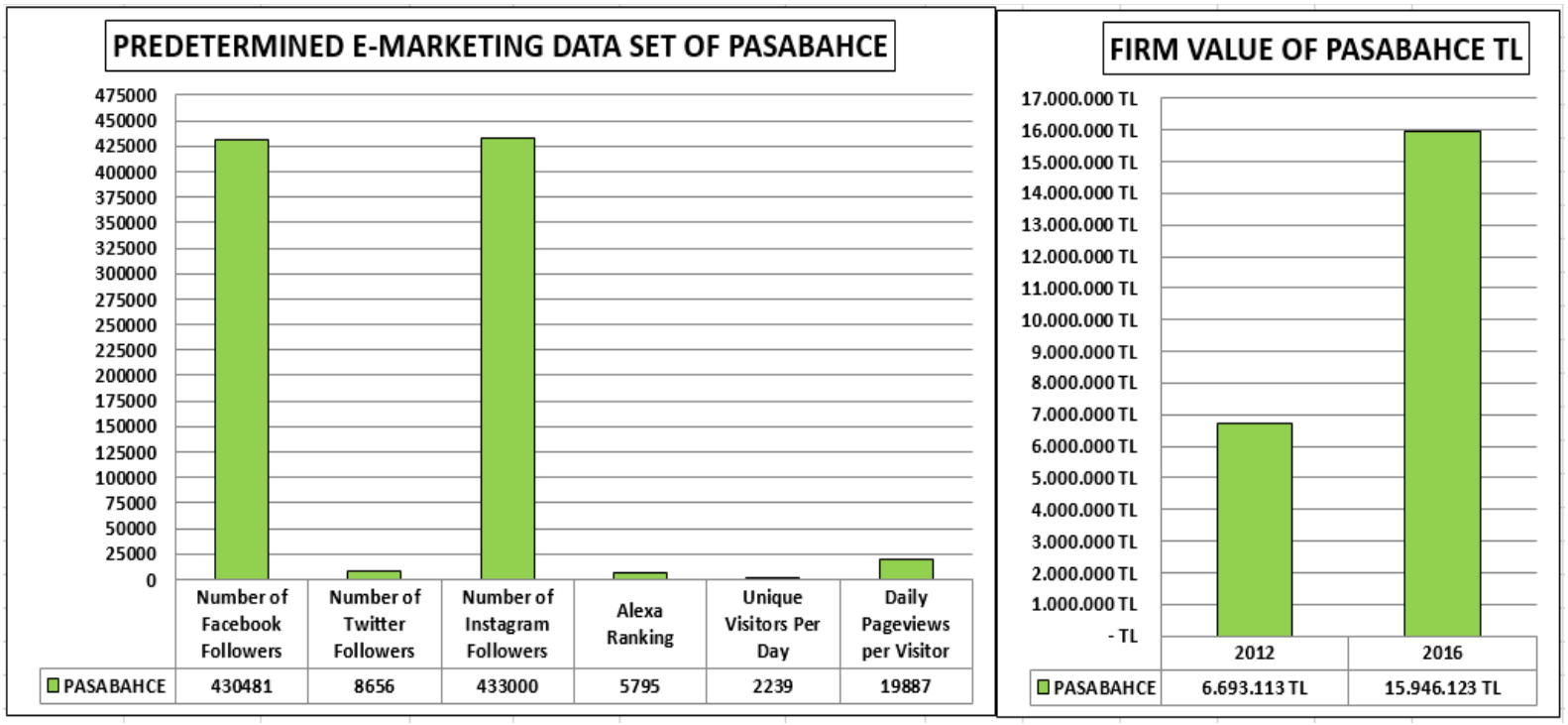

As shown in Table 9, Pasabahce has the largest number of followers on Instagram, and it is calculated that after ecommerce activities started the firm value has increased by $238 \%$, by about 2.38 times. Therefore, e-marketing has reached the point where it affects the company's value positively.

\section{CONCLUSION}

In this research, the relationship between companies' e-commerce activities and the firm value are examined with the effect of predetermined e-marketing data. To achieve this, the secondary data of the companies have been meticulously gathered and the results from these data have been evaluated and the following results have been achieved. Evaluation was made based on the number of followers in e-marketing data. The number of followers is mostly clustered on Facebook and Instagram. In addition to this, Alexa ranking of the web pages of the companies in terms of the number of visitors per day and the number of daily pageview are very important. These findings can present a point of view for the researchers about the sales of the companies on the internet that can be affected by the information these data provide. Because it has a great importance for if sales figures are affected by the followers as well as the page display on the internet. The results of this study show that these e-marketing data has a significant role in sales figures. It has come to the conclusion that businesses have increased significantly in firm value after they started e-commerce. It has been calculated that some businesses have gone up to 3 times, 5 times, or even 14 times of their worth. It also shows that number of followers of companies has not significant importance in increasing the firm value. Thus, the company's firm value which has $2,547,700$ followers increased by $13 \%$ while the company with 137,333 followers grew by $14 \%$ after e-commerce activities started. In another example, the firm value of the company with 122,916 followers increased by $11 \%$ while the company value of the company with 27,700 followers grew by $510 \%$. Besides these, e-marketing has strengthened the financial structure of the companies and caused them to become a more competitive in terms of capital structure.

The importance of e-marketing is appreciated day by day by the firms in every retail industry. In the global environment, technological developments lead the companies to increase e-marketing investments to gain competitive advantage.

The findings show that the companies that started e-commerce operations earlier do not have any superiority over the companies that started e-commerce operations later. Firm value of the companies are quite different from each other, even though the companies in the same sector have close e-commerce operations' starting dates. So, it can be said that starting dates are not very important when it comes to growth of the companies. Alexa rankings, number of daily visitors, and number of pages viewed per day were also found to be ineffective in increasing firm value.

As a result, after the introduction of e-commerce operations, it became clear that firm value of the companies increased but this growth has not been affected significantly by Facebook followers, Twitter followers, Instagram followers, Alexa rankings, number of daily visitors and number of pages viewed per day.

This study is limited to revealing the effects of e-marketing data on firm values in Turkey-based companies. In this context, interpretations are made on the data belongs to 9 companies due to time and cost constraints. For this reason, it would not 
be right to generalize this study to all companies in Turkey or in the world. In addition to this, this study has sectoral limitations because it covers several sectors in the retail industry. For the further research, studies can be conducted by using different e-marketing data set and can be analyzed using more companies with different sectors.

\section{REFERENCES}

Birgili, E., Düzer, M. (2010).Finansal Analizde Kullanılan Oranlar ve Firma Değeri ilişkisi: IMKB'de Bir Uygulama, Muhasebe ve Finansman Dergisi, 46, 74-83

Brodie, R. J., Winklhofer, H., Coviello, N. E., Johnston, W. J. (2007) Is Marketing Coming of Age? An Examination of the Penetration of EMarketing and Firm Performance, Journal of Interactive Marketing, 21 (1), 2-21

Enginkaya, E. (2006) Elektronik Perakendecilik ve Elektronik Alışveriş, Ege Akademik Bakış Dergisi, 6 (1), 10-16

Galant, V., Jakubczyc, J., Paprzycki, M. (2002). Infrastructure for E-commerce, Proceedings of the 10th Conference Extracting Knowledge from Databases, Wrocław University of Economics Press, 32-47

Hoffman D.L., Fodor M. (2010). Can You Measure the ROI of Your Social Media Marketing, MIT Sloan Management, 52 (1), $41-49$

Kalakota, Ravi, Whinston, Andrew B. (1997). Electronic commerce a manager's guide, Addison-Wesley

Krishnamurthy, S. (2006). Introducing E-Markplan: A Practical Methodology to Plan E-Marketing Activities, Business Horizons, 49 (1), $51-50$

Külter, B., Demirgüneş, K. (2006) Değer Temelli Pazarlama (Finansal Boyut ve Müşteri Boyutu), iktisat ve Idari Bilimler Dergisi, 20 (2), 327341

Özmen, H. İ., Villi, B. (2014). Sosyal Medya ve Finansal Performans: Borsa İstanbul'da İşlem Gören İşletmeler Üzerinde Bir Araştırma, AiB̈̈ Sosyal Bilimler Enstitüsü Dergisi, 14 (1), 269-293

Pauwels, K., Silve-Risso, J., Srinivasan, S., Hanssens, D. M. (2004). New Products, Sales Promotions and Firm Value: The Case of the Automobile Industry, Journal of Marketing, 68 (4), 142-156

Sarısakal, N. (2002) Veri Tabanlarının E-Ticaret Uygulamalarında Kullanılması-MNS Sigorta Şirketi Otomasyonu, İstanbul Üniversitesi Mühendislik Fakültesi Elektrik-Elektronik Dergisi, 1 (1), 41-48

Schniederjans, M. J., Cao, Q., Triche, H. H. (2014) E-commerce operation management, World Scientific Publication, 2nd Edition

Sheth, J. N., Sharma, A. (2005). International E-Marketing Opportunities and Issues, International Marketing Review, 22 (6), 611-622 